\title{
ASPEK PSIKOSOSIAL, AKTIVITAS FISIK, DAN KONSUMSI MAKANAN LANSIA DI MASYARAKAT
}

\author{
(Psychosocial Aspect, Physical Activity, and Food Consumption of the Elderly in Community) \\ Rusilanti ${ }^{1}$, Clara M Kusharto ${ }^{2}$, dan Ekawati S Wahyuni ${ }^{3}$
}

\begin{abstract}
ABST RACT
This research attempts to analyze psychosocial aspect, physical activity, and food consumption of the elderly living in the community dwelling. Research locations were chosen purposively in three POSBINDU (The Services Post for Elderly) located at areal of Bogor City, namely: Kelurahan Budi Agung (represents city-high income society), Kelurahan Baranangsiang (city-moderate to low society), and Kelurahan Situ Gede (boundary between city to rural-low income society). A simple random sampling was applied to select the subjects. One hundred ninety-seven (197) subjects aged range 60-85 years old (mean age 68.4 years) were selected in those places and completed the survey between August 2004July 2006. A cross -sectional design and one point approach was followed (Singarimbun \& Effendi, 1995). A structured questionnaire was developed to collect data about psychological aspects (family and community support; health behavior; level of depression; life satisfaction), and food consumption limited to some nutrients essensial for elderly. For physical activity assessment, each subject rated his/ her capacity involved in housekeeping. A descriptive, Chi Square, One Way ANOVA and Tuckey tests were applied to analyze the data. The research results showed that there is no significance difference among elderly in three sites in terms of psychological aspect. However, there are significance differences in health behavior and physical activity. The worst health behavior and physical activity conditions were found among elderly in Kelurahan Situ Gede caused by the social-economic differences. In terms of food consumption aspects, the significance differences exist in intake of vitamin A, vitamin B, and calcium among the subjects.
\end{abstract}

Keywords: elderly, psychosocial, physical activity, food intake, community dwelling.

\section{PENDAHULUAN}

\section{Latar Belakang}

Peningkatan jumlah penduduk lanjut usia (Iansia) merupakan salah satu tantangan pada abad 21 di seluruh dunia. Populasi penduduk dunia yang berusia di atas 65 tahun meningkat lebih dari dua kali lipat dari total populasi penduduk dunia selama periode tahun 1996 - 2020. Laju peningkatan tertinggi di Afrika Utara dan China serta beberapa negara Asia dan terendah di Sub-Saharan Afrika. Total populasi penduduk berusia di atas 65 tahun pada tahun 2025 diperkirakan lebih dari 800 juta, duapertiganya berada di negara yang sedang berkembang dan sebagian besar dari mereka adalah perempuan (United Nations, 2000).

\footnotetext{
${ }^{1}$ Staf Pengajar J urusan IKK, FT, Universitas Negeri J akarta.

${ }^{2}$ Staf Pengajar Departemen Gizi Masyarakat, Fakultas Ekologi Manusia (FEMA), IPB.

${ }^{3}$ Staf Pengajar Departemen Komunikasi dan Pengembangan Masyarakat, Fakultas Ekologi Manusia (FEMA), IPB.
}

Indonesia memiliki jumlah penduduk mencapai 201241999 jiwa dengan jumlah penduduk lanjut usia sebesar 4703694 jiwa (BPS, 2000). Berdasarkan laporan World Health Organization (WHO) pada tahun 1998 dalam Wirakusumah (2000), angka usia harapan hidup (UHH) orang Indonesia diharapkan mengalami peningkatan dari 65 tahun pada tahun 1997 menjadi 75 tahun pada tahun 2025. Hal ini dapat terjadi dengan semakin meningkatnya pelayanan kesehatan, peningkatan taraf hidup, serta berkembangnya ilmu pengetahuan dan teknologi. Artinya jumlah penduduk lansia di Indonesia juga akan terus meningkat di masa mendatang.

Arah kebijakan tentang lansia di Indonesia sebenarnya lebih menitikberatkan pada keluarga sebagai penanggungj awab utama terhadap lansia. Dalam hal ini dukungan dari keluarga sebagai care giver diharapkan menjadi kunci utama untuk kesejahteraan Iansia. (Depsos Rl, 1998).

Selain peran keluarga dan masyarakat dalam upaya merawat lansia, diperlukan juga peran pemerintah dalam memberikan fasilitas 
pada lansia seperti menyediakan tempat perawatan bagi lansia yang terlantar atau bermasalah dengan keluarga karena semakin banyaknya keluarga yang tidak mampu merawat Iansia. Dalam hal ini panti wredha merupakan salah satu alternatif bentuk bantuan pelayanan kesejahteraan sosial bagi lansia.

Isu strategis bidang kesehatan menuju Indonesia sehat 2010 adalah kerjasama lintas sektor; peningkatan perilaku, pemberdayaan masyarakat dan kemitraan swasta; peningkatan upaya kesehatan, dan peningkatan sumberdaya kesehatan (Depkes RI, 1999). Visi pembangunan kesehatan menuju Indonesia Sehat 2010 adalah masyarakat, bangsa, dan negara yang ditandai dengan penduduknya hidup dalam lingkungan dan perilaku hidup sehat, memiliki kemampuan untuk menjangkau pelayanan kesehatan yang bermutu secara adil dan merata, serta memiliki derajat kesehatan yang setinggi-tingginya di seluruh Indonesia. Sementara itu, salah satu misi pembangunan kesehatan adalah mendorong kemandirian masyarakat hidup sehat (Depkes. RI, 1999).

\section{Tujuan}

1. Menganalisis kondisi psikososial (kepuasan hidup dan depresi) lansia.

2. Menganalisis kondisi fisik (perilaku kesehatan dan aktivitas fisik) lansia.

3. Menganalisis konsumsi makan Iansia.

\section{METODE}

\section{Desain, Tempat dan Waktu Penelitian}

Penelitian ini merupakan survai penduduk usia lanjut dan rumah tangga muda yang merawat Iansia untuk mengetahui kondisi aktual dari lansia dengan menggunakan desain cross-sectional. Dalam hal ini peneliti melakukan observasi terhadap lansia tanpa melakukan intervensi. Survai dilakukan pada satu saat (point time approach), yaitu lansia serta keluarga yang merawat lansia hanya diamati sekali saja (Singarimbun \& Effendi, 1995). Pengambilan data dilakukan dengan menggunakan kuesioner dan observasi partisipasif, dalam hal ini peneliti melakukan wawancara dan pengamatan langsung terhadap sampel dan turut serta dalam kegiatan Iansia yang ada. Metode survai dipilih untuk melihat kondisi lansia, baik fisik maupun psikososial.

Penelitian ini dilakukan di Kota Bogor, yang penduduknya memiliki usia harapan hidup (UHH) 67.7 tahun pada tahun 1999, dengan jumlah jumlah lansia sebanyak 45417 orang.
Penelitian survai dilakukan di tiga wilayah puskesmas yang memiliki posbindu (pusat layanan untuk lansia) yang aktif berdasarkan rekomendasi dari Dinas Kesehatan Kota Bogor. Ketiga lokasi posbindu tersebut memiliki karakteristik latar belakang ekonomi yang berbeda. Budi Agung (BA) mewakili daerah dengan latar belakang ekonomi menengah ke atas, Baranangsiang (BS) mewakili latar belakang ekonomi yang menengah dan sebagian termasuk rendah, sedangkan Situ Gede (SG) mewakili daerah desa dengan kondisi sosial ekonomi rendah. Penelitian dilakukan pada bulan Agustus 2004 - J uni 2006.

\section{Populasi dan Sampel}

Populasi dari penelitian ini adalah Iansia yang berada di Kota Bogor dengan sampel yang diambil adalah lansia yang berada di masyarakat yang aktif mengunjungi Posbindu.

\section{Prosedur Penarikan Contoh}

Pemilihan Posbindu dilakukan berdasarkan informasi yang diberikan pihak Dinas Kesehatan Kota Bogor, yaitu Posbindu yang aktif dalam melaksanakan kegiatan. Pemilihan Posbindu dilakukan secara purposif yaitu yang mewakili daerah dengan tingkat sosial ekonomi tinggi, menengah dan kurang. Pemilihan sampel di posbindu dilakukan secara acak sederhana (simple random sampling) berdasarkan kriteria pemilihan sampel yaitu: tidak pikun, tidak bermasalah dengan pendengaran, dan bersedia diwawancara. Di samping lansia, responden juga diambil dari keluarga yang mengurus lansia (yang berada satu rumah dengan lansia) serta keluarga yang turut merawat namun tidak serumah dengan lansia.

Pendekatan awal dalam pemilihan sampel dilakukan dengan menghubungi pihak Dinas Kesehatan Kota Bogor, Dokter Puskesmas, dan dengan pengurus (kader posbindu) serta pengurus RW setempat untuk mendapatkan informasi dari lansia yang berada di masyarakat. Pertemuan pertama dengan sampel dilakukan di posbindu kemudian dilanjutkan dengan wawancara dari rumah ke rumah untuk mendapatkan informasi dari rumah tangga lansia dan rumah tangga muda yang mengurus Iansia, serta rumah tangga muda yang turut merawat namun tidak serumah dengan lansia. Total sampel lansia yang diambil di tiga lokasi penelitian berjumlah 197 orang.

\section{Jenis dan Cara Pengumpulan Data}

Data konsumsi makanan, aktivitas fisik, dan perilaku hidup sehat diperoleh melalui 
wawancara dengan lansia serta keluarga yang merawat lansia. Data kondisi psikososial seperti kepuasan hidup dan depresi diperoleh melalui wawancara dengan Iansia.

\section{Pengolahan dan Analisis Data}

Perbedaan tingkat depresi, kepuasan, perilaku hidup sehat, dan aktivitas fisik antar lansia tiga lokasi pemukiman di masyarakat dianalisis dengan Pearson Chi-Square, sedangkan data konsumsi makanan dianalisis dengan one way ANOVA dan uji Tuckey.

\section{HASIL DAN PEMBAHASAN}

\section{Kondisi Psikososial}

\section{Kondisi mental lansia di masyarakat berdasarkan lokasi pemukiman}

Berdasarkan lokasi pemukiman Iansia di masyarakat, kondisi depresi lansia diuraikan sebagai berikut: Iansia di Budi Agung (BA) yang memiliki kondisi normal sebesar $65 \%$ di Baranangsiang (BS) sebesar 70\% dan di Situ Gede (SG) sebesar $59.5 \%$ Lansia yang mengalami depresi baik ringan maupun berat di
Budi Agung sebesar 35\% Baranangsiang sebesar 30\% dan Situ Gede sebesar 40.5\% Keadaan tersebut dapat dijelaskan pada Gambar 1.

Berdasarkan hasil analisis statistik, didapatkan bahwa tidak terdapat perbedaan yang bermakna antara kondisi psikososial lansia di lokasi perumahan yang berbeda $(p>0.05)$. Hal ini karena pada umumnya mereka memiliki dukungan sosial baik dari keluarga, masyarakat, dan pemerintah misalnya dengan adanya Posbindu (Wiradinata, 2004). Menurut Nasrun (1999) faktor psikososial seperti ada tidaknya dukungan sosial merupakan salah satu faktor yang dapat mempengaruhi depresi pada lansia.

\section{Kepuasan}

Analisis kepuasan lansia yang berada di masyarakat dengan tiga lokasi perumahan menunjukkan data sebagai berikut: Iansia yang merasa tidak puas di daerah Budi Agung sebesar 22.5\% Baranangsiang 33.7\% dan Situ Gede $41.9 \%$ Lansia yang merasa puas di daerah Budi Agung sebesar 77.5\% Baranangsiang 66. 3\% dan Situ Gede 58.1\% seperti yang terlihat pada Gambar 2.

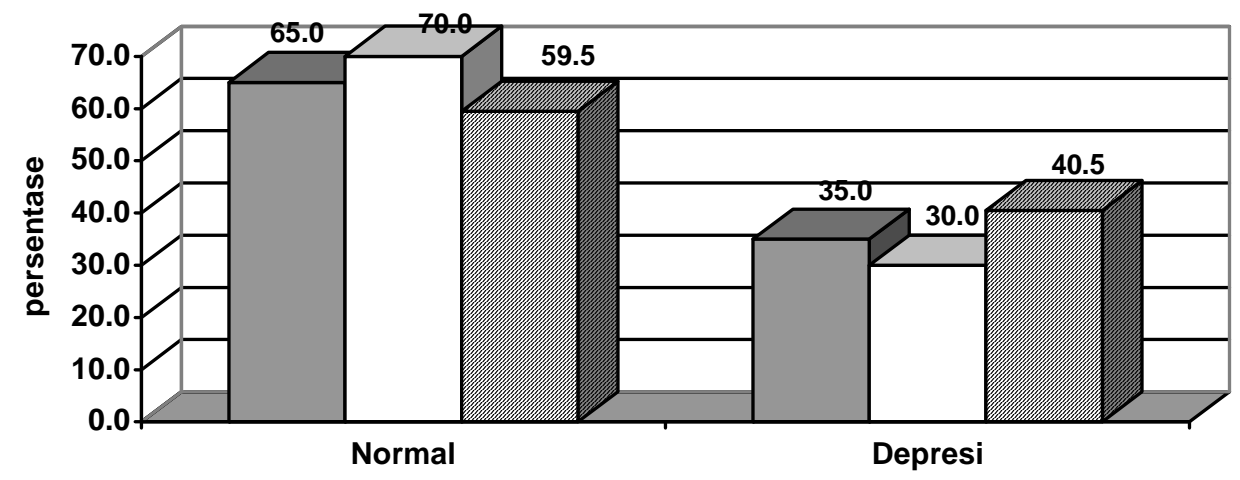

Gambar 1. Diagram Batang Sebaran Kondisi Mental Lansia (Normal dan Depresi) di Masyarakat berdasarkan Lokasi Perumahan di Kota Bogor 2005

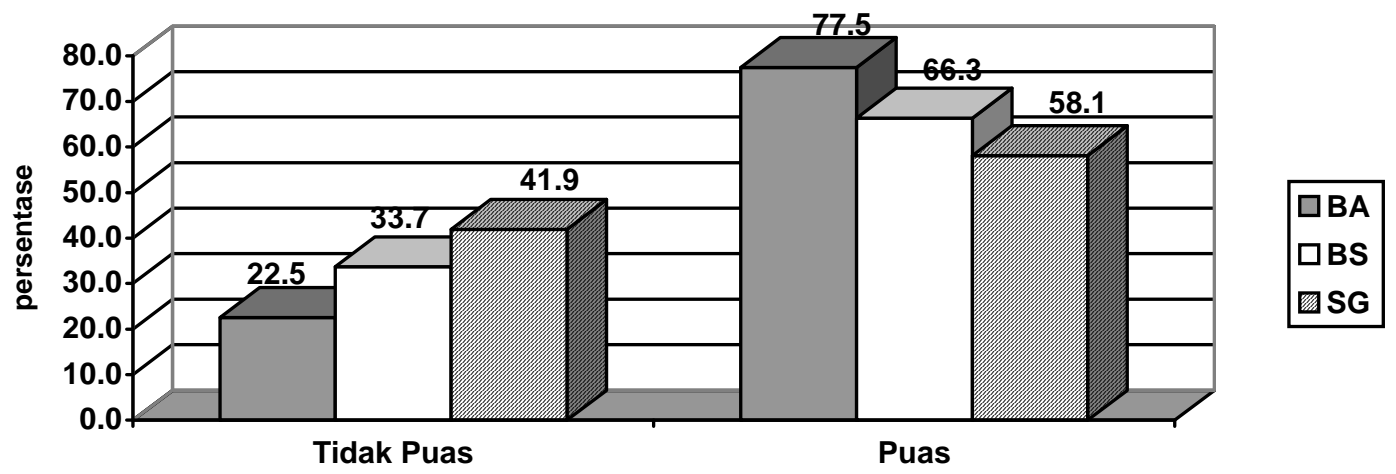

Gambar 2. Diagram Batang Sebaran Tingkat Kepuasan Lansia berdasarkan Lokasi Perumahan di Kota Bogor 2005 
Berdasarkan hasil uji beda didapatkan bahwa tidak ada perbedaan yang nyata antara tingkat kepuasan lansia di tiga lokasi perumahan ( $p$ > 0.05).

\section{Aspek Fisik}

\section{Aktivitas Fisik}

Aktivitas fisik lansia di tiga wilayah perumahan adalah sebagai berikut: lansia yang memiliki aktivitas fisik buruk di daerah Budi Agung sebesar 20\% Baranangsiang $13.8 \%$ dan Situ Gede $41.9 \%$ Lansia yang memiliki aktivitas fisik baik di daerah Budi Agung sebesar 80\% Baranangsiang 86.3\% Situ Gede 58.1\% Gambar 3 menjelaskan kondisi aktivitas fisik lansia di masyarakat berdasarkan lokasi perumahan.

Hasil uji beda menunjukkan bahwa aktivitas fisik lansia yang tinggal di daerah Budi Agung, Baranangsiang, dan Situ Gede berbeda sangat nyata $(p<0.01)$. Tingginya tingkat aktivitas fisik yang buruk dari lansia yang berada di Situ Gede dapat dipengaruhi oleh rendahnya tingkat sosial ekonomi mereka, hal ini dapat dilihat dari kondisi perumahan lansia.

Secara umum keadaan lansia di Situ Gede masih memprihatinkan, kurangnya kemampuan keluarga dalam memberikan dukungan finansial menyebabkan kurangnya biaya pengobatan bagi lansia serta kualitas makanan yang dikonsumsi oleh Iansia. Keadaan ini disebabkan karena keadaan ekonomi anak-anaknya yang masih rendah sehingga dukungan finansial dari mereka masih sangat terbatas dan beberapa masih bergantung pada Iansia.

\section{Perilaku kesehatan}

Bila dilihat dari lokasi perumahan, lansia yang memiliki perilaku kesehatan baik di Budi Agung sebesar $85 \%$ Baranangsiang $66.3 \%$ dan Situ Gede $55.4 \%$ Lansia yang memiliki perilaku kesehatan kurang di Budi Agung sebesar 15\% Baranangsiang 33.8\% dan Situ Gede $44.6 \%$ Gambar 4 menunjukkan perbedaan perilaku antar lokasi perumahan lansia.

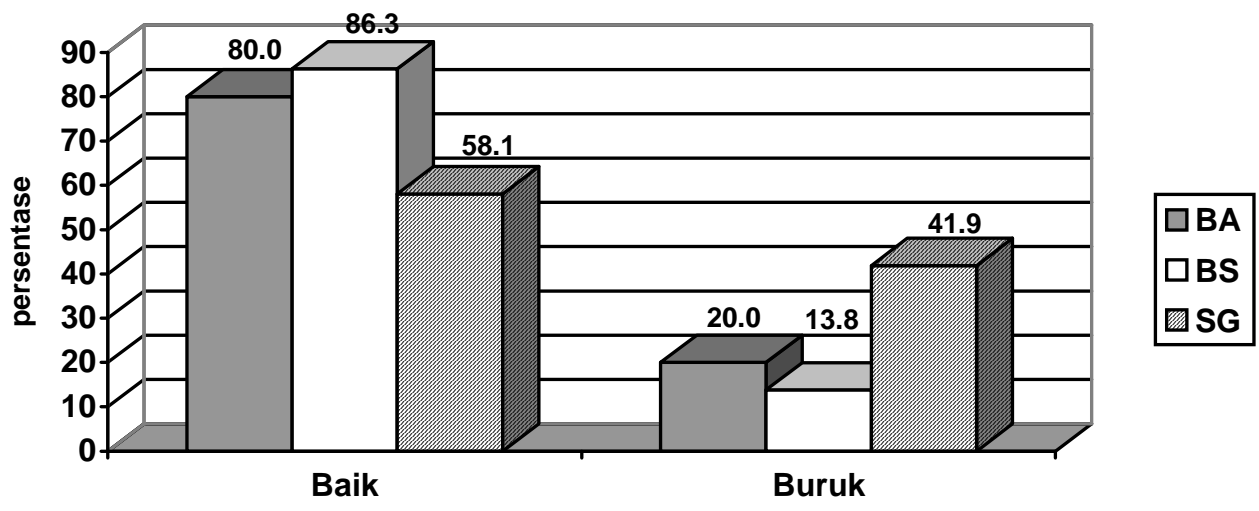

Gambar 3. Diagram Batang Sebaran Aktivitas Fisik Lansia berdasarkan Lokasi Perumahan di Kota Bogor 2005

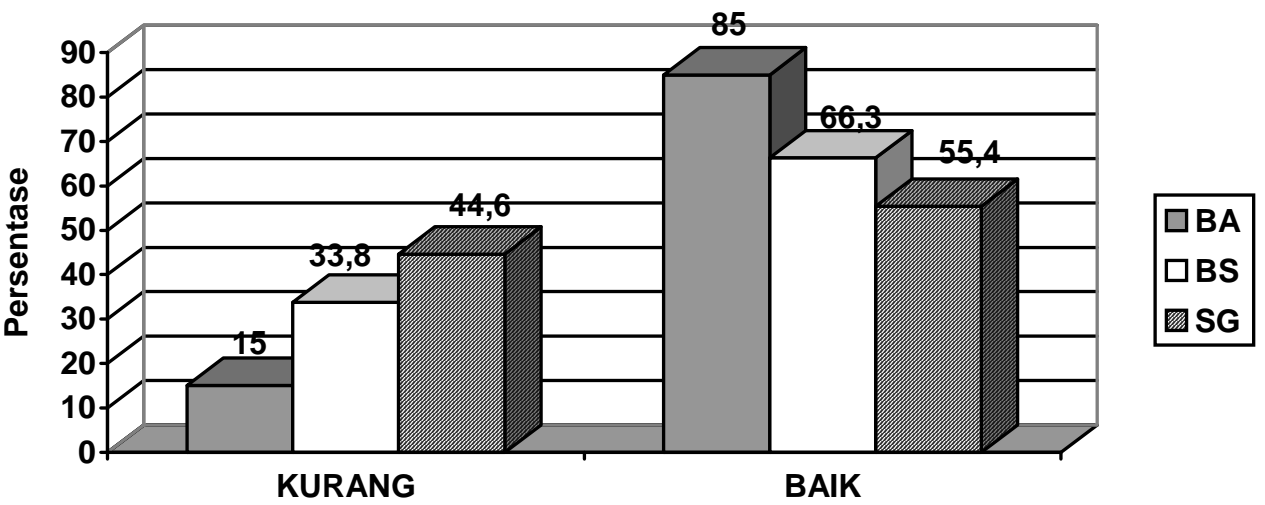

Gambar 4. Diagram Batang Sebaran Perilaku Kesehatan Lansia berdasarkan Lokasi Perumahan di Kota Bogor 2005 
Data tersebut menunjukkan bahwa lansia di Situ Gede paling banyak yang memiliki perilaku kurang terhadap kesehatan. Berdasarkan hasil uji statistik ditemukan bahwa terdapat perbedaan yang bermakna antara perilaku lansia yang tinggal Budi Agung, Baranangsiang dan Situ Gede $(p<0.05)$. Kondisi ini dapat terjadi karena keadaan sosial ekonominya yang buruk seperti rendahnya pendidikan dan kurangnya kemampuan finansial.

Hal ini didukung oleh pendapat Notoatmojo (1997) yang menyatakan bahwa adanya perbedaan pengetahuan, kecerdasan, persepsi, emosi, motivasi, sosial-ekonomi, kebudayaan dapat mempengaruhi perilaku kesehatan seseorang. Sebagian besar lansia di Situ Gede memiliki latar belakang sosial ekonomi lebih rendah dibandingkan dua kelompok lainnya. Keadaan tersebut dapat dilihat berdasarkan kondisi perumahan yang mencerminkan keadaan sosial ekonomi mereka, sehingga wajar bila hampir separuh dari mereka memiliki perilaku hidup sehat yang kurang baik.

\section{Analisis Rata-rata Konsumsi Lansia di Masya- rakat berdasarkan Lokasi Perumahan}

Konsumsi lansia di masyarakat lebih beragam bila dibandingkan dengan lansia di panti wredha. Berdasarkan lokasi perumahan lansia di masyarakat terdapat sebaran ratarata konsumsi, kecukupan konsumsi, dan persentase kecukupan konsumsi seperti yang tertera pada Tabel 1.

Data pada Tabel 1 menunjukkan ratarata konsumsi energi lansia di Budi Agung, Baranangsiang, dan Situ Gede berturut-turut:
$1572 \mathrm{Kkal}, 1595 \mathrm{Kkal}$, dan $1500 \mathrm{Kkal}$; rata-rata konsumsi protein: $47.5 \mathrm{~g}, 47.3 \mathrm{~g}$, dan $50.9 \mathrm{~g}$; rata-rata konsumsi vitamin $\mathrm{A}: 417 \mu \mathrm{gRE}, 385$ $\mu \mathrm{gRE}$, dan $297 \mu \mathrm{gRE}$; rata-rata konsumsi vitamin B: $1.1 \mathrm{mg}, 1.8 \mathrm{mg}$, dan $1.5 \mathrm{mg}$; rata-rata konsumsi vitamin C: $55 \mathrm{mg}, 60 \mathrm{mg}$, dan $50 \mathrm{mg}$; rata-rata konsumsi kalsium: $539 \mathrm{mg}, 575 \mathrm{mg}$, dan $444 \mathrm{mg}$; rata-rata konsumsi phospor: 568 mg, 575 mg, dan 646; rata-rata konsumsi Besi: $12.1 \mathrm{mg}, 13.2 \mathrm{mg}$, dan $11.9 \mathrm{mg}$.

Berdasarkan analisis uji beda dengan menggunakan one-way ANOVA didapatkan hasil sebagai berikut:

1. Terdapat perbedaan yang bermakna antara konsumsi vitamin $A(p<0.05)$, vitamin $B$ $(p<0.05)$ dan Kalsium $(p<0.01)$ pada Iansia yang berada di tiga lokasi perumahan.

2. Tidak terdapat perbedaan yang bermakna antara konsumsi energi, protein, phospor, dan besi pada lansia yang berada di tiga lokasi perumahan.

Setelah dilakukan uji lanjut dengan Tuckey, maka didapat bahwa perbedaan nyata konsumsi vitamin A terdapat pada lansia di Budi Agung dengan Situ Gede $(p<0.05)$. Perbedaan nyata konsumsi vitamin B terdapat pada lansia di Budi Agung dan Baranangsiang, hal ini terjadi karena konsumsi makanan pokok lansia di Baranangsiang lebih tinggi dibandingkan dengan lansia di Budi Agung. Perbedaan nyata konsumsi kalsium terdapat pada lansia di Budi agung dan Baranangsiang ( $p$ $<0.01$ ), ini dapat terjadi karena konsumsi makanan sumber kalsium seperti susu lebih tinggi pada lansia di Budi agung dibandingkan Baranangsiang.

Tabel 1. Konsumsi, Kecukupan Konsumsi, dan Persentase Kecukupan Konsumsi Lansia di Masyarakat Berdasarkan Lokasi Perumahan, Kota Bogor 2005.

\begin{tabular}{|l|r|r|r|r|r|r|r|r|r|}
\hline \multirow{2}{*}{ Zat Gizi } & \multicolumn{3}{|c|}{ Budi Agung } & \multicolumn{3}{c|}{ Baranangsiang } & \multicolumn{3}{|c|}{ Situ Gede } \\
\cline { 2 - 11 } & kons & Keckp & \%keckp & kons & Keckp & \%keckp & Kons & Keckp & \%keckp \\
\hline Energi (Kkal) & 1572 & 2073 & 76.3 & 1595 & 1911 & 83.12 & 1499 & 1952 & 77.1 \\
\hline Protein (g) & 47.5 & 52.8 & 91.2 & 47.3 & 48.0 & 95.8 & 50.9 & 49.7 & 102.8 \\
\hline Vit. A (mgRE) & 417 & 563 & 74.6 & 385 & 514 & 76.3 & 297 & 530 & 56.1 \\
\hline Vit. B (mg) & 1.1 & 1.0 & 106.1 & 1.8 & 1.0 & 187.4 & 1.5 & 1.0 & 160.3 \\
\hline Vit. C (mg) & 55 & 62 & 88.9 & 60 & 58 & 103.1 & 50 & 58 & 86.1 \\
\hline Kalsium. (mg) & 539 & 518 & 104.9 & 323 & 480 & 67 & 444 & 458 & 158.9 \\
\hline Phospor. (mg) & 568 & 488 & 117.2 & 575 & 452 & 126.0 & 646 & 459 & 140.4 \\
\hline Besi (mg) & 12.1 & 14.0 & 86.3 & 13.2 & 13.1 & 102.1 & 11.9 & 13.1 & 91.5 \\
\hline
\end{tabular}

Kons $=$ konsumsi, keckp = kecukupan, $\%$ keckp $=\%$ kecukupan 
Analisis Rata-rata Persentase Kecukupan Konsumsi Lansia di Masyarakat berdasarkan Lokasi Perumahan

Analisis rata-rata persentase kecukupan konsumsi Iansia berdasarkan lokasi perumahan adalah sebagai berikut: rata-rata persentase kecukupan konsumsi energi lansia di Budi Agung, Baranangsiang, dan Situ Gede berturut-turut: $76.3 \%$ 83.2\% dan $77.1 \%$ rata-rata persentase kecukupan konsumsi protein: 91.2\% 95.8\% dan 96.5\% rata-rata persentase kecukupan konsumsi vitamin A: 74.6\% 76.3\% dan $56.1 \%$ rata-rata persentase kecukupan konsumsi vitamin B: $106.1 \% \quad 187.4 \%$ dan $160.3 \%$ rata-rata persentase kecukupan konsumsi vitamin C: $88.9 \%$ 103.1\% dan $86.1 \%$ rata-rata persentase kecukupan konsumsi kalsium: $104.9 \% 67.3 \%$ dan $158.9 \%$ rata-rata persentase kecukupan konsumsi phospor: $117.2 \% \quad 126.0 \%$ dan $140.4 \%$ rata-rata persentase kecukupan konsumsi Besi: 66.3\% $102.1 \%$ dan $91.5 \%$ Untuk lebih jelasnya dapat dilihat pada Tabel 1.

Hasil uji beda dengan one-way ANOVA menunjukkan adanya perbedaan nyata pada persentase kecukupan konsumsi vitamin $A$ ( $p$ $<0.05)$ dan vitamin $B(p<0.05)$, selebihnya tidak terdapat perbedaan nyata. Selanjutnya berdasarkan hasil uji Tukey, didapat adanya perbedaan persentase kecukupan yang bermakna untuk konsumsi vitamin $A(p<0.05)$ pada lansia di Baranangsiang dan Situ Gede. Lansia di Situ Gede sangat sedikit mengonsumsi bahan makanan sumber vitamin $A$ seperti buah dan bahan makanan sumber protein hewani. Hal in sangat erat kaitannya dengan faktor ekonomi. Sementara itu terdapat perbedaan persentase kecukupan vitamin B $(p<0.01)$ pada lansia di Budi Agung dan Baranangsiang. Perbedaan nyata persentase konsumsi vitamin B juga terdapat pada Iansia di Situ Gede dan Budi Agung ( $p<0.05$ ), karena lansia di Situ Gede lebih banyak mengonsumsi bahan makanan sumber vitamin B seperti beras.

\section{KESIMPULAN DAN SARAN}

\section{Kesimpulan}

Tidak ada perbedaan yang bermakna pada kondisi psikososial (mencakup kepuasan dan depresi) pada tiga lokasi pemukiman lansia di masyarakat. Namun ditemukan perbedaan yang bermakna pada aktivitas fisik dan perilaku kesehatan antar lansia yang berada di tiga lokasi pemukiman lansia di ma- syarakat. Lansia yang tinggal di daerah Situ Gede memiliki kemampuan fisik dan perilaku kesehatan yang lebih buruk dibandingkan dua kelompok lainnya, yaitu Budi Agung dan Baranangsiang $(p<0.01$ dan $p<0.01)$. Pada lansia yang tinggal di masyarakat berdasarkan lokasi perumahan terdapat perbedaan yang bermakna pada konsumsi vitamin $A(p<0.05)$, vitamin $B(p<0.01)$, dan kalsium $(p<0.01)$, sedangkan perbedaan nyata persentase kecukupan konsumsi lansia di masyarakat antar ketiga lokasi perumahan adalah pada persentase kecukupan konsumsi vitamin $A(p<$ $0.05)$, vitamin $B(p<0.01)$, dan kalsium $(p<$ $0.05)$.

Dengan demikian dapat disimpulkan bahwa perbedaan lokasi pemukiman lansia berdasarkan kondisi sosial ekonomi dapat menyebabkan adanya perbedaan aktifitas fisik dan perilaku kesehatan pada lansia yang berada di masyarakat. Namun adanya dukungan keluarga, masyarakat, dan pemerintah dapat menciptakan kondisi lanjut usia yang tidak terganggu aspek psikososialnya (hidup puas dan tidak depresi).

\section{Saran}

Mengingat kondisi psikososial lansia yang tidak berbeda di antara lokasi pemukiman, maka lansia dapat tinggal di mana saja asalkan tetap mendapatkan perhatian atau dukungan, baik dari keluarga, masyarakat maupun pemerintah. Misalnya dapat dibentuk wadah tempat Iansia bersosialisasi bersama peer groupnya. Untuk meningkatkan aktifitas fisik dan perilaku kesehatan, hendaknya difasilitasi dengan memberi kesejahteraan berupa dukungan moril dan sprituil kepada kelompok lansia.

\section{DAFTAR PUSTAKA}

Depsos RI. 1998. Undang-Undang Republik Indonesia Nomor 13 Tahun 1998 Tentang Kesejahteraan Lanjut Usia. Departemen Sosial, J akarta

BPS. 2000. Statistika Indonesia (Statistical Year Book of Indonesia). BPS, J akarta

DepKes RI, 1999 Indonesia Sehat 2010: Visi Baru, Misi, Kebijakan dan Strategi Pembangunan Kesehatan. Departemen Kesehatan, J akarta

Nasrun MW. 1999. Depresi Dan Komobiditasnya Pada Pasien Usia Lanjut. Jiwa. 
Majalah Psikiatri. Indonesian Psychriatric Quarterly. Yayasan Kesehatan J iwa "Dharmawangsa", J akarta

Notoatmojo S. 1997. IImu Kesehatan Masyarakat. Rineka Cipta, J akarta

Singarimbun $M \&$ \& Effendi. 1995. Metode Penelitian Survai. Pustaka LP3ES Indonesia, Jakarta

United Nations. 2000. The World Nutrition Situation (4 th edition). United Nations, Administrative Commitee on Coordination Sub-Committee on Nutrition (ACC/SCN) in Collaboration with International Food Policy Research Institute. New York
Wada T, M Ishine, T Sakagami, K Okumiya, M Fujikawa, S Murakami, K Otsuka, S Yano, T Kita, \& K Matsubayashi. 2004. Depression in Japanese Communitydwelling elderly-prevalence and association within ADL and QOL. Arch. Gerontol. Geriatr. ELSEVIER.

Wiradinata. 2004. Latar Belakang, Kondisi Fisik, Mental dan Aktifitas pada Lanjut Usia di Panti Wredha Sukma Rahardja dan Pos Pembinaan Terpadu Kelurahan Situgede, Kota Bogor. Skripsi Sarjana Jurusan Gizi Masyarakat dan Sumberdaya Keluarga, Fakultas Pertanian, IPB, Bogor.

Wirakusumah E. 2002. Tetap Bugar Di usia Lanjut. Trubus Agriwidya, J akarta 